\title{
STUDY ON THE NUTRIENT ADEQUACY OF FEEDS FOR PET RABBITS AVAILABLE IN THE ITALIAN MARKET
}

\author{
Ricci R., Sartori A., Palagiano C., Dalle Zotte A. \\ Department of Animal Science, University of Padova. Agripolis. Viale dell’Università 16. 35020 LegnARo. Italy.
}

\begin{abstract}
This study was carried out to determine the proximate composition and nutritional adequacy of six complete commercial feeds for pet rabbits available in the Italian market. Wide variability was observed in the chemical composition of the complete feeds selected. Two feeds exceeded crude protein recommended level $(172 \mathrm{~g} / \mathrm{kg}$ and $182 \mathrm{~g} / \mathrm{kg}$ ), whereas $50 \%$ of the diets selected did not meet the minimal crude fibre requirements of $130 \mathrm{~g} / \mathrm{kg}$. The estimated digestible energy (DE) showed an oversupply in five feeds, attributable to high starch content (from 195 to $380 \mathrm{~g} / \mathrm{kg}$ ) in four of them. Fat levels resulted adequate in all feeds (between 10 and $50 \mathrm{~g} / \mathrm{kg}$ ), whereas a wide variability was observed in fatty acid (FA) composition. All feeds were deficient in phosphorus $(<5 \mathrm{~g} / \mathrm{kg}$ ) and three of them also in calcium $(<8 \mathrm{~g} / \mathrm{kg})$. All feeds were below the minimal vitamin E requirements $(<40 \mathrm{mg} / \mathrm{kg})$. One feed showed an aflatoxin B1 content of $11.36 \mu \mathrm{g} / \mathrm{kg}$ which is slightly higher than the European recommended maximum amount of $10 \mu \mathrm{g} / \mathrm{kg}$. The six pet rabbit feeds obtained from the Italian market did not fulfil the nutrient requirements for pet rabbits and feeding animals with these products might produce detrimental health effects in the long term.
\end{abstract}

Key Words: Pet rabbit, complete feed, proximate composition, fatty acid profile, aflatoxins.

\section{INTRODUCTION}

In Italy, France and Spain, rabbits are intensively reared for meat production, while all across Europe, particularly Germany and the UK, or in countries like the USA and Canada, they have become increasingly popular as pets (Santomá et al., 1989). The estimated 5.7 million pet rabbits in the USA makes them the third most popular pet mammal after dogs and cats (Irlbeck, 2001). Pet rabbits are also becoming more popular in Italy, where the smaller breeds such as Dwarf Lop are the most widespread. The adequate hygiene of both the environment and the animal is essential to avoid a variety of bacterial problems (Martino and Luzi, 2008). Although correct feeding promotes good health, information on pet rabbit nutrient requirements and feeding is scarce, whereas many studies have been dedicated to commercial and laboratory rabbits. Pet rabbits have a potentially much longer lifespan than those reared for meat production or experimental purposes, and many common ailments like gastrointestinal and dental diseases seen in companion rabbits can be directly linked to a prolonged inadequate nutrient supply. Health problems caused by incorrect nutrition are the most common reasons why pet rabbit owners consult veterinarians (Harrenstien, 1999). 
Considering the close relationship between dietary characteristics and pet rabbits' health, this study aimed to evaluate the proximate composition of commercial pet rabbit diets available in the Italian market and assess their nutritional adequacy. Moreover, fatty acid profile was taken into consideration in order to obtain exhaustive information on the quality of pet rabbit foods; whereas aflatoxin content was measured to verify potential contamination of the diets.

\section{MATERIALS AND METHODS}

\section{Feeds}

Six commercial feeds (A, B, C, D, E, F) with different physical characteristics formulated for the maintenance of adult pet rabbits were collected from the Italian market: three were feeds (A, B, C) composed of a mixture of whole seeds, cereal flakes, pellets and dried pieces of vegetables as indicated on the package label; two diets were composed of extruded kibbles only (D, F) and one of pellets only (E). Collected feeds were available in packages ranging from 500 to $1500 \mathrm{~g}$ in weight. Entire content was finely ground $(1 \mathrm{~mm})$ and used for chemical analyses.

\section{Chemical analysis}

AOAC procedures (2000) were used to determine in duplicate dry matter (DM, 934.01, by using $5 \mathrm{~g}$ of samples at $103^{\circ} \mathrm{C}$ for $5 \mathrm{~h}$ ), ash $(942.05)$, crude protein (CP, 976.05), crude fibre (CF, 978.10), and neutral detergent fibre (NDF, 2000.04), acid detergent fibre and acid detergent lignin (ADF and ADL, 973.18) by using the Ankom Technology (Macedon, NY 14502) with filter bags (F57). Total dietary fibre (TDF) and its insoluble (IDF) and soluble (SDF) fractions were determined by gravimetric/enzymatic procedure (991.43). Ether extract (EE, 920.39) was determined after acid-hydrolysis, whereas starch with amyloglucosidase-a-amylase method (996.11). Gross energy (GE) was determined by adiabatic bomb calorimetry (ISO, 1998). The digestible energy (DE) content was estimated by using the prediction equation for DE n. 9 (DE=0.015 CP+0.037 EE+0.016 Starch+0.018 RES+0.013 Hemicelluloses -0.0003 Cellulose - 0.008 Lignin (sa)) proposed by Villamide et al. (2009), where RES corresponds to organic matter-CP-EE-NDF-Starch.

Mineral analysis (Ca, K, Na, P) was performed by ICP-OES (Spectro Ciros Vision EOP) after microwave digestion (AOAC 2000, 999.10), whereas AOAC procedure 943.01 was used for chlorine determination. Vitamin E contents were determined by following the methods described in the ISTISAN Report 1996/34.

The fatty acid (FA) profile was analysed by gas chromatography (GC), after Folch extraction (Folch et al., 1957). Transmethylation was carried out using $100 \mu \mathrm{L}$ of sodium methoxide and $150 \mu \mathrm{L}$ of oxalic acid. GC was performed on an automated apparatus (Shimadzu GC 17A Japan) equipped with flame ionisation detector and a Supelco Omegawax 250 type capillary column (30 $\mathrm{m} \times 0.25 \mathrm{~mm} \mathrm{ID)}$ ). Characteristic operating conditions were the following: injector temperature: $260^{\circ} \mathrm{C}$; detector temperature: $260^{\circ} \mathrm{C}$; He 6.0 flow: $1.30 \mathrm{~mL} / \mathrm{min}$ (linear velocity: $35 \mathrm{~cm} / \mathrm{sec}$ at $220^{\circ} \mathrm{C}$ ). Fatty acids were identified by comparing their retention times to those of authentic FA methyl ester standards (Mix C4-24, 18919-1AMP, Supelco, Bellefonte, PA, USA). Results were expressed as a percentage (w/w) of total FA methyl esters.

Aflatoxin (AFs) B1, B2, G1 and G2 content was determined with a rapid and sensitive reversed-phase high-performance liquid chromatographic method (Stroka and Anklam, 2000). 
Table 1: Chemical composition ( $\mathrm{g} / \mathrm{kg}$ as fed) and nutritive value of the six commercial pet rabbit feeds.

\begin{tabular}{|c|c|c|c|c|c|c|c|c|}
\hline & \multirow{2}{*}{$\begin{array}{l}\text { Nutrient } \\
\text { requirements }\end{array}$} & \multicolumn{6}{|c|}{ Feeds } & \multirow[b]{2}{*}{$\mathrm{CV}^{2}$} \\
\hline & & $\mathrm{A}$ & $\mathrm{B}$ & $\mathrm{C}$ & $\mathrm{D}$ & $\mathrm{E}$ & $\mathrm{F}$ & \\
\hline Physical characteristics ${ }^{3}$ & & M & M & M & $\mathrm{E}$ & $\mathrm{P}$ & $\mathrm{E}$ & \\
\hline Dry matter (DM) & & 889 & 883 & 888 & 920 & 892 & 923 & 2.0 \\
\hline Ash & na & 47 & 39 & 49 & 82 & 74 & 74 & 29.6 \\
\hline Crude protein $(\mathrm{CP})$ & $120-160$ & 129 & 120 & 116 & 172 & 136 & 182 & 19.6 \\
\hline Ether extract (EE) & $20-50$ & 50 & 45 & 45 & 42 & 23 & 46 & 23.9 \\
\hline Crude fibre (CF) & $130-200$ & 105 & 79 & 96 & 133 & 202 & 137 & 35.1 \\
\hline Total dietary fibre (TDF) & $300-400$ & 285 & 233 & 281 & 357 & 482 & 356 & 26.5 \\
\hline Insoluble dietary fibre (IDF) & $125-150$ & 256 & 212 & 247 & 352 & 457 & 350 & 29.1 \\
\hline $\mathrm{NDF}$ & na & 223 & 202 & 210 & 330 & 419 & 307 & 30.5 \\
\hline $\mathrm{ADF}$ & $150-200$ & 117 & 92 & 114 & 163 & 244 & 165 & 36.2 \\
\hline ADL & na & 28 & 21 & 23 & 46 & 43 & 42 & 32.5 \\
\hline Starch & $0-135$ & 278 & 380 & 295 & 195 & 88 & 144 & 47.0 \\
\hline Gross Energy, MJ/kg & na & 17.1 & 16.1 & 16.5 & 17.7 & 17.2 & 17.9 & 4.1 \\
\hline Digestible Energy (DE) MJ/ $\mathrm{kg}^{4}$ & $09-10$ & 12.7 & 12.6 & 12.3 & 10.8 & 9.0 & 11.3 & 12.2 \\
\hline $\mathrm{CP} / \mathrm{DE}, \mathrm{g} / \mathrm{MJ}^{5}$ & na & 10.2 & 9.6 & 9.4 & 15.9 & 15.2 & 16.1 & 25.9 \\
\hline $\mathrm{Ca}$ & $08-10$ & 5.3 & 4.1 & 5.5 & 8.7 & 8.5 & 10.0 & 34.2 \\
\hline $\mathrm{P}$ & $05-08$ & 3.4 & 3.1 & 3.3 & 4.9 & 2.9 & 3.8 & 19.6 \\
\hline $\mathrm{Ca}: \mathrm{P}$ & $1: 1-2: 1$ & $1.56: 1$ & $1.32: 1$ & $1.67: 1$ & $1.77: 1$ & $2.93: 1$ & $2.63: 1$ & 32.3 \\
\hline $\mathrm{K}$ & 06-07 & 7.9 & 6.2 & 7.6 & 8.7 & 12 & 9.8 & 23.0 \\
\hline Chlorine & na & 5.4 & 5.3 & 5.8 & 3.7 & 3.0 & 4.2 & 24.1 \\
\hline $\mathrm{Na}$ & na & 1.1 & 0.7 & 1.2 & 2.6 & 1.6 & 1.6 & 47.7 \\
\hline Vitamin E, mg/kg & $40-70$ & 29.1 & 21.2 & 25.7 & 32.2 & 25.2 & 37.8 & 20.3 \\
\hline
\end{tabular}

${ }^{1}$ Nutrient requirements range for pet rabbits at maintenance (Lowe, 1998). ${ }^{2}$ Coefficient of variation. ${ }^{3} \mathrm{M}$ : mixture diet, E: extruded diet, P: pelleted diet. ${ }^{4}$ Calculated according to the equation n. 9 proposed by Villamide et al., 2009. ${ }^{5}$ Calculated.

na: values not available for pet rabbits.

\section{RESULTS AND DISCUSSION}

The results of chemical analyses performed on the six feeds are shown in Table 1. Only four of them showed comparable CP content (on average $125 \mathrm{~g} / \mathrm{kg}$ ) close to the values of $120-160 \mathrm{~g} / \mathrm{kg}$ recommended to cover adult pet rabbit protein maintenance requirements (Lowe, 1998), whereas feeds D and F showed a higher CP level (172 and $182 \mathrm{~g} / \mathrm{kg}$, respectively). An optimal dietary CP level depends on its digestibility and DE content. A recommended ratio of 14-15 g CP/MJ DE was suggested to both optimise the growth rate and restrain mortality in growing and fattening rabbits (Carabaño et al., 2009). This CP/DE ratio can be considered suitable also for adult pet rabbits (Lowe, 1998) and may even be reduced by $10 \%$ when the amino acid supply is correct (García-Palomares et al., 2006). Based on these considerations, feeds A, B and $\mathrm{C}$ exhibited low $\mathrm{CP} / \mathrm{DE}$ ratio $(10.2,9.6$ and $9.4 \mathrm{~g} / \mathrm{MJ}$ respectively), whereas feeds $\mathrm{D}$ and $\mathrm{F}$ showed improperly high $\mathrm{CP} / \mathrm{DE}$ ratio (15.9 and $16.1 \mathrm{~g} / \mathrm{MJ}$ respectively). 
A wide variability in CF content (from 79 to $202 \mathrm{~g} / \mathrm{kg}$ ) and fibre fractions obtained by the sequential procedure (NDF: from 202 to $419 \mathrm{~g} / \mathrm{kg}$; ADF: from 92 to $244 \mathrm{~g} / \mathrm{kg}$; ADL: from 21 to $46 \mathrm{~g} / \mathrm{kg}$ ) was observed in the six feeds. CF content is an important aspect of the diets for pet rabbits because they do not need to convert food as efficiently as commercial rabbits. These diets should also promote intestinal motility and maintain body weight (Hartcourt-Brown, 2002), moreover, providing pet rabbits with adequate amounts of IDF prevents undesirable behaviour, like chewing non-food items at home or barbering (HartcourtBrown, 2002). Lowe (1998) reported that a sufficient IDF content ( $90 \mathrm{~g} / \mathrm{kg}$ diet) would be provided with $130-140 \mathrm{~g} / \mathrm{kg}$ of dietary CF, but higher contents (CF levels of 130-160 g/kg and IDF level of 125-150 g/ $\mathrm{kg}$ ) are advised. Although the required IDF level was provided by all feeds considered, ranging from 212 to $457 \mathrm{~g} / \mathrm{kg}$, a wide variability in CF content was observed, and only feeds D, E and F were included in the range recommended by Lowe (1998). In this study, feeds A, B and C did not even reach $320 \mathrm{~g}$ TDF/ $\mathrm{kg}$ (DM basis), which is the minimum level found in complete feeds used for growing rabbits (Gidenne, 2003). This parameter should be reconsidered when formulating feeds for pet rabbits because they are in constant maintenance regime and the TDF intake should therefore be maximised.

Feeds showed a wide range of starch content, which varied from $88 \mathrm{~g} / \mathrm{kg}$ of feed $\mathrm{E}$ to $380 \mathrm{~g} / \mathrm{kg}$ of feed B. The estimated DE content varied from 9.0 MJ/kg DM in feed E to $12.7 \mathrm{MJ} / \mathrm{kg} \mathrm{DM}$ in feed A. Only feed E filled the recommended DE requirements of 9 to $10 \mathrm{MJ} / \mathrm{kg}$ suggested for pet rabbits (Lowe, 1998). The remaining 5 feeds exceeded the advised DE content for fattening rabbit feeds $(10.5 \mathrm{MJ} / \mathrm{kg})$, and four cases (feeds A, B, C, F) even exceeded the level recommended for breeding does (11.1 MJ/kg) (De Blas and Mateos, 1998). These high-energy diets may lead to obesity in pet rabbits in the long-term. The high $\mathrm{DE}$ content observed in diets $\mathrm{A}, \mathrm{B}$ and $\mathrm{C}$ could be due to their high starch level. For young rabbits the starch level is advisable to range from 0 to a maximum $135 \mathrm{~g} / \mathrm{kg}$, whereas for adult pets no constraint needs to be considered (Lowe, 1998). However, some authors suggest limiting the starch content to less than $150 \mathrm{~g} / \mathrm{kg}$ to avoid gastrointestinal dysmicrobism on adult rabbits (Lowe, 1998). With the exception of $\mathrm{E}(88 \mathrm{~g} / \mathrm{kg})$ and $\mathrm{F}(144 \mathrm{~g} / \mathrm{kg})$, the remaining feeds exceeded the more restricted recommendations available for adults (from $195 \mathrm{~g} / \mathrm{kg}$ in feed D to $380 \mathrm{~g} / \mathrm{kg}$ in feed B). Too much starch in diets could cause gastrointestinal dysmicrobism and digestive disorders also in pet rabbits in maintenance regimes (Irlbeck, 2001). Moreover, if Clostridium spp. are present in the gut, toxin production can occur and lead to severe enteritis and increased mortality rates (Jenkins, 1999). Low fat levels are required in pet rabbit diets, and should range from 10 to $50 \mathrm{~g} / \mathrm{kg}$ (Lowe, 1998; Hartcourt-Brown, 2002). All the feeds studied met this requirement.

Calcium (Ca) content was lower than the recommended level of 8-10 g/kg (Lowe, 1998) in feeds A, B and $\mathrm{C}$. Due to their continuous teeth growth, pet rabbits require a constant supply of $\mathrm{Ca}$ (Harcourt-Brown, 2002) and Ca deficiency has been implicated in dental diseases (Harcourt-Brown and Baker, 2001) and poor bone quality (Harcourt-Brown, 1996). Phosphorus (P) was below recommendations (5-8 g/kg) in all feeds. Once adequate $\mathrm{Ca}$ and $\mathrm{P}$ levels are reached in pet rabbit diets, another important parameter to take into account is their ratio, which should be maintained between 1:1 and 2:1 in favour of Ca (Lowe, 1998). Dental diseases can also result from imbalanced Ca:P ratios. Feeds E and F exceeded the recommended ratio accounting for 2.93:1 and 2.63:1, respectively; however, only feed D simultaneously fulfilled the $\mathrm{Ca}$ and $\mathrm{P}$ levels and the $\mathrm{Ca}: \mathrm{P}$ ratio indicated for a proper maintenance dietary regime. Particular attention should be given to those rations composed of a mixture of whole ingredients (A, B, C) because rabbits are selective feeders and could reject pellets and whole grains (Harcourt-Brown, 1996). Since feed manufacturers incorporate minerals and vitamins in the pellets, their rejection from the diet can lead to nutritional deficiencies (Harcourt-Brown, 1996).

All the feeds analysed showed deficiencies in vitamin E content. The correct suggested dietary amount is around $50 \mathrm{mg} / \mathrm{kg}$ (Castellini et al., 2007) or between 40 and $70 \mathrm{mg} / \mathrm{kg}$ (Lowe, 1998) for the dual 
Table 2: Fatty acid composition (\% of total fatty acid) of the six commercial pet rabbit feeds.

\begin{tabular}{|c|c|c|c|c|c|c|}
\hline & \multicolumn{6}{|c|}{ Feeds } \\
\hline & A & B & $\mathrm{C}$ & D & $\mathrm{E}$ & $\mathrm{F}$ \\
\hline C10:0 & 0.02 & 0.01 & 0.06 & 0.02 & 0.02 & 0.02 \\
\hline C12:0 & 0.06 & 0.02 & 0.08 & 0.72 & 0.18 & 0.07 \\
\hline C14:0 & 0.34 & 0.13 & 0.18 & 0.48 & 0.40 & 0.36 \\
\hline C15:0 & 0.07 & 0.10 & 0.06 & 0.06 & 0.16 & 0.08 \\
\hline C16:0 & 12.4 & 11.4 & 10.6 & 12.6 & 15.8 & 14.1 \\
\hline C17:0 & 0.13 & 0.09 & 0.11 & 0.10 & 0.19 & 0.16 \\
\hline C18:0 & 4.49 & 3.03 & 2.51 & 2.96 & 2.49 & 2.89 \\
\hline C20:0 & 0.42 & 0.41 & 0.36 & 0.35 & 0.48 & 0.41 \\
\hline $\mathrm{C} 22: 0$ & 0.45 & 0.51 & 0.52 & 0.34 & 0.46 & 0.41 \\
\hline C23:0 & 0.07 & 0.02 & 0.04 & 0.08 & 0.24 & 0.20 \\
\hline $\mathrm{C} 24: 0$ & 0.24 & 0.24 & 0.29 & 0.25 & 0.45 & 0.29 \\
\hline Total SFA & 18.6 & 15.9 & 14.7 & 17.2 & 20.7 & 18.9 \\
\hline C14:1 & 0.00 & 0.00 & 0.01 & 0.02 & 0.12 & 0.14 \\
\hline C16:1 & 0.48 & 0.13 & 0.16 & 0.20 & 0.26 & 0.14 \\
\hline C17:1 & 0.08 & 0.02 & 0.07 & 0.02 & 0.13 & 0.07 \\
\hline $\mathrm{C} 18: 1 n-9$ & 27.7 & 23.9 & 33.6 & 18.9 & 16.4 & 15.9 \\
\hline $\mathrm{C} 18: 1 n-11$ & 1.42 & 0.72 & 0.81 & 1.06 & 1.25 & 1.03 \\
\hline $\mathrm{C} 20: 1 n-9$ & 0.55 & 0.12 & 0.20 & 0.17 & 0.20 & 0.11 \\
\hline $\mathrm{C} 22: 1 n-9$ & 0.16 & 0.09 & 0.11 & 0.27 & 0.30 & 0.20 \\
\hline $\mathrm{C} 24: 1 n-9$ & 0.04 & 0.09 & 0.04 & 0.06 & 0.03 & 0.02 \\
\hline Total MUFA & 30.4 & 25.0 & 35.0 & 20.6 & 18.7 & 17.6 \\
\hline C18:2n-6 & 45.8 & 55.2 & 46.4 & 42.0 & 39.8 & 47.3 \\
\hline $\mathrm{C} 18: 3 n-3$ & 3.29 & 2.29 & 2.57 & 18.5 & 17.2 & 12.5 \\
\hline C18:2 c9t11 & 0.11 & 0.00 & 0.05 & 0.00 & 0.00 & 0.05 \\
\hline C18:2 t10c12 & 0.06 & 0.00 & 0.05 & 0.00 & 0.02 & 0.09 \\
\hline C20:2 & 0.09 & 0.05 & 0.05 & 0.06 & 0.05 & 0.06 \\
\hline $\mathrm{C} 20: 3 n-3$ & 0.00 & 0.07 & 0.04 & 0.00 & 0.10 & 0.05 \\
\hline C20:4n-6 & 0.20 & 0.12 & 0.07 & 0.06 & 0.21 & 0.08 \\
\hline $\mathrm{C} 20: 5 n-3$ & 0.04 & 0.09 & 0.05 & 0.06 & 0.02 & 0.05 \\
\hline $\mathrm{C} 22: 5 n-3$ & 0.00 & 0.02 & 0.00 & 0.03 & 0.00 & 0.06 \\
\hline $\mathrm{C} 22: 6 n-3$ & 0.07 & 0.00 & 0.00 & 0.02 & 0.00 & 0.03 \\
\hline Total PUFA & 49.8 & 57.8 & 49.3 & 60.8 & 57.3 & 60.3 \\
\hline$n-6 / n-3$ & 13.7 & 23.2 & 17.8 & 2.27 & 2.31 & 3.74 \\
\hline
\end{tabular}


Table 3: Aflatoxin content $(\mu \mathrm{g} / \mathrm{kg})$ of the six commercial pet rabbit feeds.

\begin{tabular}{lcccccc}
\hline & \multicolumn{7}{c}{ Feeds } \\
\cline { 2 - 7 } & $\mathrm{A}$ & $\mathrm{B}$ & $\mathrm{C}$ & $\mathrm{D}$ & $\mathrm{E}$ & $\mathrm{F}$ \\
\hline B1 Aflatoxin & 0.10 & 0.12 & 11.36 & 0.10 & 0.05 & 0.02 \\
B2 Aflatoxin & 0.05 & 0.05 & 1.12 & 0.02 & 0.05 & 0.02 \\
G1 Aflatoxin & 0.50 & 0.36 & 0.19 & 0.12 & 0.14 & 0.24 \\
G2 Aflatoxin & 0.17 & 0.29 & 0.19 & 0.12 & 0.19 & 0.07 \\
\hline
\end{tabular}

purpose of preventing nutritional deficiency in the animals and PUFA oxidation in the feed. Insufficient vitamin E intake can lead to several diseases, such as muscular dystrophy and myocardial dysfunction, and increased incidence of coccidiosis has also been observed (Borgman, 1966; Lowe, 1998). Results achieved in vitamin E content allow considerations on the actual need for such supplementation usually adopted by manufacturers and the possibility of at least a more reasonable use of nutrient supplements.

Table 2 shows the FA of the six feeds. Feeds B, D, E and F were found to have very high polyunsaturated fatty acid content (PUFA) $(57.8,60.8,57.3$ and 60.3\% total FA respectively) compared to feeds A (49.8\% total FA) and $\mathrm{C}(49.3 \%$ total FA), which is mainly attributable to their higher linolenic acid (C18:3 $n$-3) content $(18.5,17.2$, and $12.5 \%$ total FA of feeds $\mathrm{D}, \mathrm{E}$ and $\mathrm{F}$, respectively). Feeds $\mathrm{D}, \mathrm{E}$ and $\mathrm{F}$ also demonstrated a healthier $n-6 / n-3$ ratios $(2.27,2.31$ and 3.74 , respectively). Recent results with mice indicated that $n-3$ FA enriched diets fed ad libitum prolong lifespan longer than $n-6$ FA by enhancing antioxidant enzymes and lowering pro-inflammatory cytokines (Fernandes, 2008). PUFA have also been shown to reduce body weight and fat deposition in animal models, thus preventing against obesity (Li et $a l ., 2008)$. Moreover, data available from different animal species suggest that $n-3$ PUFA can improve host resistance to a number of pathogens including bacteria, viral and parasitic agents (Anderson and Fritsche, 2002). Nevertheless, further research should be carried out to provide more information on FA requirements and on the healthiest $n-6 / n-3$ ratio in diets for pet rabbits.

The aflatoxin content (B1, B2, G1, G2) of the six feeds is shown in Table 3. The aflatoxin B1 content $(11.36 \mu \mathrm{g} / \mathrm{kg})$ found in feed $\mathrm{C}$ was slightly higher than that set out by the European Union in Directive 2003/100/EC (10 $\mu \mathrm{g} / \mathrm{kg}$ ) for complete animal feeds (including those for rabbits). This result should be given particular consideration since rabbits are known to be highly susceptible to aflatoxins. Aflatoxin B1 toxicity can cause damage to the liver, kidney, thyroid, testicles, and brain (Mézes and Balogh, 2009). More specifically, feeds contaminated with $15 \mu \mathrm{g} / \mathrm{kg}$ aflatoxin B1 were shown to cause haemolytic anaemia in rabbits (Verma and Mehta, 1998) and $100 \mu \mathrm{g}$ aflaxoxin B1/kg feed has the potential to induce teratogenic effects and chronic intoxication in this species (Wangikar et al., 2005). Strict regular monitoring of raw materials and storage conditions in the pet food industry should be recommended to avoid aflatoxin contamination.

\section{CONCLUSIONS}

Analysis of the six commercial rabbit pet feeds showed them to be extremely heterogeneous in chemical composition and often not proper in terms of pet rabbit nutrient requirements. In particular, starch content and DE exceeded recommendations considerably in most of the feeds analysed, and if high-energy diets are fed for a long period, obesity can occur and contribute to the reduction of animal lifespan. On the other hand, TDF intake should be maximised. Great attention should be also paid to the levels and ratios of minerals, especially $\mathrm{Ca}$ and $\mathrm{P}$ due to their role in the manifestation of dental disease and urolithiasis, 
and vitamin E. Finally, further studies are required to offset the lack of information on pet rabbit nutrition and feeding.

Acknowledgements: This study was supported by Valman s.r.l., Isola Vicentina (VI), Italy. The authors would like to thank Luciano Magro and Sandro Tenti for technical support.

\section{REFERENCES}

Anderson M., Fritsche K.L. 2002. (n-3) Fatty acids and infectious disease resistance. J. Nutr. 132: 3566-3576.

AOAC 2000. Official Methods of Analysis. $17^{\text {th }}$ ed. Association Of Official Analytical Chemists, Gaithersburg, Mariland, USA, 208772417.

Borgman R.G. 1966. The effect of feeding rabbits a vitamin E-low diet containing oleic acid. Am. J. Vet. Res., 27: 809-813.

Carabaño R., Villamide M.J., García J., Nicodemus N., Llorente A., Chamorro S., Menoyo D., García-Rebollar P., García-Ruiz A.I., De Blas J.C. 2009. New concepts and objectives for protein-amino acid nutrition in rabbits: a review. World Rabbit Sci., 17: 1-14.

Castellini C., Mourvaki E., Dal Bosco A., Galli F. 2007. Vitamin E Biochemistry and Function: a case study in Male Rabbit. Reprod. Domest. Anim., 42: 248-256.

De Blas J.C., Mateos G.G. 1998. Feed formulation. In: De Blas J.C., Wiseman J. (ed). The nutrition of the rabbit. CABI Publishing. Wallingford. UK. pp. 241-253.

European Community 2003. 2003/100/EC. Commission Directive 2003/100/EC of 31 October 2003 amending Annex I to Directive 2002/32/EC of the European Parliament and of the Council on undesirable substances in animal feed. Off. J. Eur. Union, L 285: 33-37.

Fernandes G. 2008. Progress in nutritional immunology. Immunol. Res., 40: 244-261.

Folch J., Lees M., Sloane Stanley G.H. 1957. A simple method for the isolation and purification of total lipids from animal tissues. J. Biol. Chem., 226: 497-509.

García-Palomares J., Carabaño R., García-Rebollar P., De Blas J.C., Corujo A., García-Ruiz A.I. 2006. Effects of a dietary protein reduction and enzyme supplementation on growth performance in the fattening period. World Rabbit Sci., 14: 231-236.

Gidenne T. 2003. Fibres in rabbit feeding for digestive troubles prevention: respective role of low-digested and digestible fibre. Livest. Prod. Sci., 8: 105-117.

Harcourt-Brown F.M. 1996. Calcium deficiency, diet and dental disease in pet rabbits. Vet. Rec., 139: 567-571.

Harcourt-Brown F.M., Baker S.J. 2001. Parathyroid hormone, haematological and biochemical parameters in relation to dental disease and husbandry in rabbits. J. Small Anim. Pract., 42: 130136.

Harcourt-Brown F.M. 2002. Textbook of rabbit medicine. Oxford, UK, Butterworth Heinemann.

Harrenstien L. 1999. Gastrointestinal diseases of pet rabbits. J. Exotic Pet Med., 8: 83-89.
Irlbeck N.A. 2001. How to feed the rabbit (Oryctolagus cuniculus) gastrointestinal tract. J. Anim. Sci., 79 (E. Suppl.): 343-346.

ISO 1998. Animal feeding stuffs, animal products and faeces or urine. Determination of gross calorific value - Bomb calorimetric method. Reference number 9831.

ISTISAN report, 1996/34. 1996. Analytical method used in food chemical control. Baldini M., Fabietti F., Giammarioli S., Onori R., Orefice L., Stacchini A. (Eds.), pp. 265. ${ }^{\circ}$ Istituto Superiore di Sanità, ISSN 1123-3117. http://www.iss.it/binary/publ/cont/9634. $p d f$

Jenkins J.R. 1999. Feeding recommendations for the house rabbit. Vet. Clin. Exot. Anim., 2: 143-151.

Li J.J., Huang C.J., Xie D. 2008. Anti-obesity effects of conjugated linoleic acid, docosahexaenoic acid, and eicosapentaenoic acid. Mol. Nutr. Food Res., 52: 631-645.

Lowe J.A. 1998. Pet rabbit feeding and nutrition. In: De Blas C., Wiseman J. (ed), The nutrition of the rabbit. CABI Publishing. Wallingford. UK. pp. 309-332.

Martino P.A., Luzi F. 2008. Bacterial infections in rabbit as companion animal: a survey of diagnostic samples in Italy. In Proc.: $9^{\text {th }}$ World Rabbit Congress, 10-13 June, 2008. Verona, Italy. 1013-1018.

Mézes M., Balogh K. 2009. Mycotoxins in rabbit feed: a review. World Rabbit Sci., 17: 53-62.

Santomá G., De Blas J.C., Carabaño R., Fraga M.J. 1989. Nutrition of rabbits. In: Haresign W., Cole D.J.A. (ed.), Recent Advances in Animal Nutrition. Butterworths, London, 109-138.

Stroka J., Anklam E. 2000. Immunoaffinity column cleanup with liquid chromatography using post-column bromination for determination of aflatoxins in peanut butter, pistachio paste, fig paste, and paprika powder: collaborative study. J. AOAC Int., 83: 320-340.

Verma R.J., Mehta D.N. 1998. Occurance of hemolytic anemia during aflatoxicosis. Indian J. Environ. Toxicol., 8: 5-7.

Villamide M.J., Carabaño R., Maertens L., Pascual J.J., Gidenne T., Falcao-E-Cunha L., Xiccato G. 2009. Prediction of the nutritional value of European compound feeds for rabbits by chemical components and in vitro analysis. Anim. Feed Sci. Tech., 150: 283294.

Wangikar P.B., Dwivedi P., Sinha N., Sharma A.K., Telang A.G. 2005. Teratogenic effects in rabbits of simultaneous exposure to ochratoxin A and aflatoxin B1 with special reference to microscopic effects. Toxicology, 215: 37-47. 